phrase, to his "sympathetic treatment" of proteins during extraction and manipulation. His work in the laboratory was dominated by an awareness that proteins are an integral part of living tissue. $\mathrm{He}$ had great intellectual capacity but also a deep intuitive understanding of both things and people.

Bailey's unusual combination of gifts included an ability to write in a clear and attractive style. Vivid phrases recurred and gave his articles a freshness not often found in scientific literature. Once, in reviewing a rather speculative book, he wrote characteristically of the difficulty in "separating the gems of fact from the trinkets of fancy". He was co-editor of The Proteins, a past member of the Editorial Board of the Biochemical Journal and a joint editor of Advances in Protein Chemistry. Many have reason to be grateful for his ability and patience in changing a turgid typescript into a comprehensible paper. Not surprisingly, these same qualities made him an excellent teacher both in the Biochemistry Department and in Trinity College of which he was elected a Fellow in 1948.

The past ten years of Bailey's life were marred by severe, recurrent illness, but the intervening periods were mercifully long and he was able to continue his fruitful work and retain his creative interest in music, sculpture, poetry and painting. Bailey was a kind, sensitive and gentle person who will be remembered with gratitude and deep affection by his many friends throughout the world.

\section{R. R. Porter}

\section{Prof. C. H. Lobban}

Prof. Charles H. Lobban, who held the chair of civil engineering in King's College, University of London, from 1935 until his retirement in 1946, died on July 13, at the age of eighty-two.

Lobban studied civil engineering at the University of Glasgow and then trained, by pupilage, as a professional engineer. His subsequent career was interesting because it was devoted initially to university teaching, then to professional practice and then to both activities pursued simultaneously. $\mathrm{He}$ served first as demonstrator and lecturer in his own University of Glasgow during 190406, as lecturer at Manchester during 1906-08 and as professor at Madras during 1908-10. He then entered a consulting engineering practice in Kilmarnock and so continued until he was caught up, like most of his generation, in the maelstrom of the First World War. He saw three and a half years of active service in France as a major in the Royal Engineers and was mostly concerned with logistics and vital railway installations. I recall his vivid description of the drama when the 'secret weapon' of the War, the tank, was first brought to the Front. He was wounded in action, but with him this was never a cause for vainglory.

In 1920 his career again took one of its changes in direction when he was appointed lecturer in eivil engineering in King's College, London, becoming senior lecturer in 1923 and reader in 1926 . This was a most fruitful period of his life because he found it possible to combine his teaching of civil engineering with the practice of it. During this time he was responsible for the engineering design of some notable London buildings including Victoria House and the School of Hygiene and Tropical Medicine. He also had charge of some university buildings at Nottingham and elsewhere. In 1935 he succeeded Prof. A. H. Jameson in the chair of civil engineering at King's College, in which appointment he remained until his retirement in 1946. His period of tenure of the chair at King's College was difficult. $\mathrm{He}$ had but a brief time to develop his Department before the outbreak of the Second World War when the College was evacuated to Bristol. There he continued to keep a team together amidst many anxieties, and, equally difficult, to face and organize their return to the war-damaged and dilapidated buildings in the Strand, shortly before he retired.

Lobban's interests were mainly centered on the structural aspects of civil engineering both in his practice, in teaching and in research. He was not a voluminous writer, but was the author of a number of papers dealing with aspects of structural theory. In particular, he was interested in the analysis of structural frames by applying known deformations to a model whereby the stresses in the full-sized structure could be determined. The procedure originated in the United States, but Lobban was one of the first to develop it in Great Britain. In 1924 he was awarded the D.Sc. of the University of Glasgow for a thesis entitled "Grillage and Reinforced Concrete Foundations", a subject in which he was much involved as the engineer for heavy buildings founded on London Clay. Other writings were concerned with the deflexions of structures and the bending of girders when encased in concrete. He also served for a time as technical officer to the Steel Structures Research Committee of the Department of Scientific and Industrial Research.

Lobban had a gift for economy both in the use of words and in the kind of calculations which a civil engineer must undertake. This quality was most evident in his methods of structural analysis; for problems in this field he could usually produce elegant short methods not to be found in the text-books. He was a devoted and most effective teacher whose lectures carried the conviction and inspiration of one who was teaching what he practised. Students not only recognized his authoritative standing in his profession but also admired him as a man, and he enjoyed an enviable popularity with them. A keen golfer, he was captain of Hampstead Golf Club in 1936 and after his retirement became a keen curler. He also delighted in yachting, usually off the west coast of his beloved Scotland, and groups of students generally formed his eager, willing crew. Prof. Lobban will be remembered with respect and affection by generations of his former students.

A. D. Ross

\section{Prof. J. Satterly}

THE death on October 1 of Prof. John Satterly at the age of eighty-three has severed one of the few remaining ties between Canada and the Cavendish Laboratory of J. J. Thomson's days at the beginning of the century. He brought to the University of Toronto an enthusiasm for physics and the delights of experimental investigation which he retained even after he retired from active teaching in 1950.

In his lectures to the first-year students in the honours course in mathematics and physics, which was attended also by students intending to pursue advanced study of biology, he was a vigorous successful teacher. He is remembered by generations of former students, including men and women who are now teachers on the staff of the University, for the training they received from him to be scrupulous and observant. Among American teachers of physics, his papers on the physics of simple phenomena which can be observed even in the kitchen are very well known. He was not an atomic physicist, but, in my own opinion, Satterly's spirit of modest investigation is sadly missing in much of the research and teaching of physics to-day.

Satterly was a Devon man with a deep knowledge of its history. He loved England and was full of historical anecdotes of British science. $\mathrm{He}$ was a close personal friend of Dr. Searle - a link with Clerk Maxwell.

In the Royal Society of Canada to which he was elected in 1917, he was a genial member, and he was well known as a popular lecturer in Toronto, for he showed a fine spirit of fun on these occasions. His achievement is shown in the lives of those who were influenced by him.

W. H. Watson 